\title{
PROTECTIONISM, PRESTIGE, AND NATIONAL SECURITY: THE ALLIANCE AGAINST MULTILATERAL TRADE IN INTERNATIONAL AIR TRANSPORT
}

\author{
RANDALL D. LEHNER
}

"When we inch forward where we could step forward, we are not carrying out our obligations to the peoples of the world."

\section{INTRODUCTION}

This statement could correctly describe the present day situation of international trade in air transport, yet a Canadian delegate made this statement almost fifty years earlier in reference to a inultilateral agreement for the excliange of commercial rights among nations in international aviation. The similarities between the current and past situations in international air services are both striking and unsettling. They are striking in the sense that nore than fifty years after the conclusion of the Chicago Conference, the flying world only lias inclied forward in the development of a multilateral excliange of air traffic riglits. At the same time, these similarities should unsettle any nation, interest group, or advocate of a liberalized trading regime for international air transport. Many of the same arguments used in 1948 to block the creation of a multilateral agreement are employed today not only to prevent the developinent of a inultilateral agreement but also to stymie debate and discussion of the ways to overcome many of the practical difficulties associated with such a treaty. Although this problem may seem at first glance like little more than a policy complication, the continuing impediments to a multilateral agreement for international aviation violate the spirit, if not the letter, of inany international accords dealing with aviation and trade in services. The issue remains what type of change is needed in the legal structure of international air transport. This Note

1. 2 Records of the Commission on Multilateral Agreement on Commercial Rights im International Air Transport pt. 1, at 152, ICAO Doc. 5230, A2-EC/10 (Apr. 1948) [hereinafter 2 Records pt. 1] (statement of J. Baldwin, Canada). 
argues that a new multilateral legal framework for international aviation is not only desirable but, if international aviation is left to languish within the current bilateral agreement structure, will be necessary as well.

To better understand the future legal structure of international air transport services, Part I of this Note discusses the need for a change in the legal structure of the industry as well as the origins and current status of the international aviation business and regulatory regime. Part II then examines the support for the current bilateral negotiation system governing international air transport. Part III analyzes the arguments and theines in the international aviation debate today and compares them with statements made decades ago both about aviation and a similarly situated industry, steel. Part IV addresses the inerits of a multilateral system. Finally, Part $V$ explores methods that might be used to advance the debate over the protectionist obstacles to a multilateral system. This Note concludes that the potential benefits of a multilateral system for regulating interuational air transport justify and require States and their airlines to make an effort to find the common ground and take the risks upon which the discussion may be advanced and results eventually may be achieved.

\section{The Chicago Convention and the Current Regime OF INTERNATIONAL AVIATION REGULATION}

A. The Legacy of Protectionism and the Need for Change

Near the end of World War II in 1944, representatives of nuany nations gathered in Chicago to discuss the future of the burgeoning international civil aviation industry. Prior to this neeting, no comprehensive legal structure governed international air services. ${ }^{2}$ The Chicago Convention emerged from that meeting, forming the basis for the international aviation regulatory systen during the last half century. ${ }^{3}$ Article I of the Chicago Convention rests upon a principle that has influenced subsequent actions and attitudes by nations smce its establishment: "The contracting States recognize that every State las complete and exclusive sovereignty

2. Both the Paris and Havana Agreements were concluded prior to the Chicago Convention, but these were not comprehensive accords. See MAREK ŻYLICZ, INTERNATIONAL AIR TRANSPORT LAW 59, 67 (1992).

3. Id. at 73 . 
over the airspace above its territory." ${ }^{4}$ This short statement has had a profound impact on the development of a multilateral agreement on imternational traffic rights, and has served as the basis for state protection and regulation of aviation markets. It also has provided the legal authority under which a nation may choose to hiberalize and open the skies above its territory. In addition, the Preamble of the Chicago Convention states that the parties agree "that international air transport services may be established on the basis of equality of opportunity," presuniably meaning that each nation would have an equivalent chance to participate in the market for providing international air transport. Countries also have employed this bedrock principle of the Convention to justify their regulatory actions concerning international aviation.

International air transport could have developed in myriad directions based on these principles of "exclusive sovereignty" and "equality of opportunity." Yet the negotiating countries created a regulatory system pointing in the direction of protectiomsm. Instead of being framed upon the principles of free trade and a hberal exchange of commercial traffic rights, the international air transport regime is based on a rigid and closed system of regulation so that nations can ensure that they "get a share of the market" that sovereignty and equal opportunity arguably guarantee. ${ }^{6}$

Since the ratification of the Chicago Convention in the 1940s, civil air transport constantly has expanded to reach new geographical areas and populations. With declining fares and technological advances, airlines have reached out to the travelling public and more people are choosing air transport for their travel needs. ${ }^{7}$ Yet this growth in passengers is problematic because the traditional legal strncture governing air travel now strains under its mission to "blend the economic realities that would accommodate changing social and technological needs with such immutable and sacrosanct principles as State sovereignty and individuahty of air carriers."

4. Convention on International Civil Aviation, opened for signature Dec. 7, 1944, art. I, 15 U.N.T.S. 295, 296 [hereinafter Chicago Convention].

5. Id. at pmbl.

6. Henri A. Wassenbergh, World Trends in Air Transport Policies, 19 AIR \& SPACE L. 174, 175 (1994); see also R.I.R. Abeyratne, The Air Traffic Rights Debate-A Legal Study, 18 ANNALS OF AIR \& SPACE L. 3, 27 (1993).

7. See infra notes $9-10$ and accompanying text.

8. Abeyratne, supra note 6, at 36-37. 
Two factors, one internal and one external to the industry, may force a change in this traditional but restrictive approach to route negotiations. First, the tremendous value and expansion of air services in terms of passenger levels during the last half-century emphasize the importance of shifting the legal perspective to a multilateral exchange of traffic rights. The growth in passengers carried by the world's airlines has been phenomenal over the past fifty years and is projected to continue growing into the new millennium. For example, Asia and the Pacific region should experience aimual growth of $11 \%$ in passenger traffic through the turn of the century. ${ }^{9}$ Even inore inature air markets, such as Europe and North America, should enjoy annual growth ranging from approximately $6-8 \%$ during the current decade. ${ }^{10}$

Second, truly free trade in goods also will require that those goods be transported under a inore liberal trade regime because of the potential economic value to be generated through air transport. Indeed, "[t]ransportation firms are the veins and arteries througl which commerce flows. ... [A]nd [this fact] makes their rate and service offerings critically important to all who require access to the inarket for the sale of their products." 11 The airlines' current contribution to the overall world economy can be seen in the numbers and value of goods transported. Total revenue froin all types of commercial airline operations has a relatively significant impact on world GNP, amounting to approximately $1.5 \%$ of all goods and services produced around the globe..$^{12}$ In fact, the international air services coinponent comprises half of those revenues. ${ }^{13}$ Moreover, the world's airlines carried approximately $25 \%$ of manufactured goods sold in international trade. ${ }^{14}$ Witlı suclı a high volume of trade carried by commercial airlines, industries dependent on air transport for their supplies or merchandise will expect and need an aviation regulatory framework that can accommodate continued expansion.

Consequently, these two growth factors, passenger levels and economic value, can operate im concert as pressures from both

\footnotetext{
9. ŻYLICZ, supra note 2 , at xvi.

10. Id.

11. Paul S. Dempsey, Airline Deregulation and Laissez-Faire Mythology: Economic Theory in Turbulence, 56 J. AIR L. \& COM. 305, 393 (1990).

12. ŻYLICZ, supra note 2 , at $\mathrm{xv}$.

13. Id.

14. Id.
} 
inside and outside the air transport business to force a new approach to negotiations of international route rights for airlines. The impediment to such change is strong because the current counbination of national sovereignty and bilateral agreements "encourages nations to approach air service negotiations mercantilistically, trading access to each other's traffic in rough proportion to the amount of traffic available."15 The economic and trading value of the services provided by the world's airlines can help break this barrier by acting as a force for change from outside of the industry. The need to serve current passengers better as well as the need to extend air service to inore potential passengers can function as a force for change from within the industry.

Furthermore, two recent developinents demonstrate the impact of the international aviation legal structure upon the travelling public. During the summer of 1995, a dispute arose between the United States and Japan regarding the rights of Federal Express, the world's leading air express cargo carrier, to route flights froin its new hub in the Philippines through Japan to other Asian destinations. ${ }^{16}$ Although the dispute ostensibly involved only cargo transport, the underlying concern driving the conflict focused on Japan's distress over what it viewed as a bilateral agreement that was skewed unfairly toward the United States. ${ }^{17}$ That agreement grants limited "beyond rights" to the two designated U.S. passenger carriers, Northwest and United Airlines, thereby allowing them to transport passengers froin Japan to other destinations within Asia. ${ }^{18}$ Japan, however, beheves that, as a result of the agreement, the U.S. carriers have built large and lucrative networks throughout Asia-networks which Japan feels should belong to its national carriers. ${ }^{19}$ Not surprisingly, the United States attributes any such success to the efficiency and coinpetitiveness of its carriers. $^{20}$ Although the two nations narrowly averted imposing trade

15. DaNiEl M. Kasper, Deregulation and Globalization: Liberalizing INTERNATIONAL TRADE IN AIR SERVICES 62 (1988).

16. Gerard Baker, Japanese Try to Turn the Tables on US, FInANCIAL TIMES, July 7, 1995 , at 3.

17. $I d$.

18. Id. "Beyond rights" are the equivalent of fifth freedom rights. See infra text accompanying note 31 .

19. Andrew Pollack, Air Dispute Causes Role Reversal; Japan, Not U.S., Seems to Favor "Managing" Trade, INT'L HeRALD TRIB., June 21, 1995, at 17.

20. Baker, supra note 16 , at 3 . 
sanctions on each other's air traffic, this episode illustrates the constraints under which airlines currently operate their services.

The second event was the inauguration of additional service between Chicago's O'Hare Airport and London's Heathrow Airport. United Airlines becaine the second designated carrier under the United States-United Kingdom bilateral agreennent known as Bermuda $\Pi{ }^{21}$ This new service should help to improve the otherwise poor position of the travelling public on the Chicago-London route. A study found that the average Chicago-London fare was higher than any other U.S. city-London fare while providing substantially less service. ${ }^{22}$ In fact, Boston and Miami, with much sinaller populations than Chicago, had significantly more nonstop seats available to London. ${ }^{23}$ The restrictive nature of the Bermuda II bilateral agreenent was responsible for this underserved and overpriced market. ${ }^{24}$ In addition to the localized negative effects, the travelling public may have felt the real impact of this route allocation because of reduced access to Heathrow, the most important hub for international destinations beyond London. ${ }^{25}$ Hence, the average traveller can face high-priced service coupled witl less availability as a result of the bilateral system-something that would not occur without such severe regulatory restraints.

\section{B. The Present State of International Civil Aviation Agreements}

The Chicago Convention created the "five freedoms" of the air. These freedoms have been used to define and restrict the extent of the traffic rights exclianged among States in their agreements and therefore dictate the ability of a nation's airlines to fly in the international inarket. ${ }^{26}$ The first two freedoins, the privi-

21. Hearings on Intemational Aviation Before the Senate Comm. on Commerce, Science, and Transportation, 104th Cong., 1st Sess. (July 11, 1995) available in LEXIS, Legis. Library, CNGTST File [hereinafter Hearings] (statement of Gerald Greenwald, Chairman and CEO, United Air Lines, Inc.).

22. Hearing on International Aviation Before the Senate Comm. on Commerce, Science, and Technology, 104th Cong., 1st Sess. (May 24, 1995), available in LEXIS, Legis. Library, CNGTST File (statement of Gerald Greenwald, Chairman and CEO, United Air Lines, Inc.) (citing 1994 study prepared for United Air Lines).

23. Id.

24. Hearings, supra note 21.

25. British Airways; We Are Flying into Turbulence, EconomIST, Mar. 4, 1995, at 64. In fact, travellers from Chicago still may feel the impact of reduced access to Heathrow because United Airlines will be able to operate ouly one flight per day on a relatively sinall aircraft until 1997. Hearings, supra note 21.

26. In addition to creating the regulatory system for international civil aviation, the 
lege to fly across the territory of a state without landing and the privilege to land for non-traffic ${ }^{27}$ purposes, were exchanged on a inultilateral basis among the contracting parties to the Chicago Convention. ${ }^{28}$

The third, fourth, and fifth freedoms, however, have been the rights traditionally desired and exchanged bilaterally between countries in their air services agreennents. The third freedom permits airlines to transport passengers and cargo from their hoine State to the territory of the other contracting State..$^{29}$ The fourth freedoin works in reverse by permitting airlines to transport passengers and cargo froin the territory of the other contracting State to the airlines' hoine State. ${ }^{30}$ The fifth freedom, often the most disputed right in international aviation exchanges, is " $t$ t]he privilege to take on passengers, inail and cargo destined for the territory of any contracting State and the privilege to put down passengers, inail and cargo coming froin any such territory." 31

The exchange of these five freedoms designated in the Chicago Convention and its supporting agreements has been the cornerstone of bilateral agreements anong countries for international

Chicago Convention established another important feature of the regulatory system that may concern the multilateral exchange of traffic rights. The Convention founded the International Civil Aviation Organization (ICAO) as the governing body for air transport. Chicago Convention, supra note 4 , art. 43 , at 324 . ICAO mainly functions as a technical and advisory body to nations and their airlines as well as an organizing agency to discuss issues confronting transnational aviation. Id. arts. 37, 44, at 320,326 . ICAO has the potential to serve as the catalyst for pushing a multilateral system but has not yet taken that role.

27. Non-traffic purposes are those landings that do not involve the pick-up or dropoff of passengers. For example, refuehing or maintenance adjustments in the course of a flight path would be non-traffic landings.

28. International Air Services Transit Agreement, opened for signature Dec. 7, 1944, art. I, 84 U.N.T.S. 389, 390.

29. International Air Transport Agreement, opened for signature Dec. 7, 1944, art. 1, 171 U.N.T.S. $387,388$.

30. Id. at 390.

31. Id. More concrete examples of these freedoms will help to illustrate their critical influence on international air routes. A third freedom right, under a bilateral agreement between France and the United States for example, would give Delta Airlines the right to carry passengers from Atlanta (these would be passengers taken on in the airline's home territory) to Paris. Corresponding closely with the third freedom, a fourth freedoin right would allow Delta to carry passengers from Paris to Atlanta (these would be passengers destined for the airhne's home territory). Finally, a fifth freedoin right could be used on a multilateral basis, allowing Delta to carry passengers from Atlanta to Paris to Rome (provided that the United States, France, and Italy were all party to such an agreement). 
aviation commercial rights. "Airlines are not free to enter international markets on their own. An airline must be designated by its government to provide service on an international route, or acquire the right from another airline so designated." 32 Bilateral agreements concluded between nations usually incorporate these designations and often include a variety of regulations covering numerous aspects of international aviation. ${ }^{33}$ The type of regulations that may be included in a bilateral agreement can be broken down into two broad categories: "hard" and "soft" rights. Hard rights are those that are typically economic in nature; they encoinpass such matters as traffic and route rights, airline designation, capacity controls, and pricing. ${ }^{34}$ Soft, or ancillary rights, cover issues that assist with airline operations; these include currency exchanges, ground and baggage handling, and airport usage..$^{35}$

The degree of tberalization contained in bilateral agreements varies widely. Nonetheless, the scope of the regulations applicable to air carriers distinguishes three general types of bilateral agreements. The nost liberal bilateral accords allow for such rights as multiple designation of airlines ${ }^{36}$ little or no capacity or frequency controls on routes, and greater market access to the contracting parties' gateways. ${ }^{37}$ The middle position of bilateral regnlation is characterized by a "regulated freedom" permitting airlines to determine certain issues such as gateways and pricing subject to governmental oversight. ${ }^{38}$ This forn of agreement is known as the "Berinuda-type," referring to the agreement that has governed air service between the United States and the United Kingdom for

32. THE ECONOMIC EFFECTS OF SIGNIFICANT U.S. IMPORT RESTRAINTS, PHASE III: SERVICES, USITC Pub. 2422, Inv. No. 332-262, 1991 ITC LEXIS 1014, *23 (Sept. 1991) [hereinafter ECONOMIC EFFECTS].

33. See Alexandre Mencik von Zebinsky, The General Agreement on Trade in Services: Its Implications for Air Transport, 18 ANNALS OF AIR \& SPACE L. 359, 392 (1993).

34. ŻYICZ, supra note 2, at 139. Hard rights are viewed as inore economic in nature because the right and frequency to serve certain markets determine the extent of route networks on which an airline nay operate and has a direct impact on an air carrier's sources and flow of income.

35. Id.

36. Multiple designation of airlines refers to the ability of a state to decide that more than one of its flag carriers will be permitted to operate a route. A practical example might be the right of both Japan Airlines and All Nippon Airways to fly from Tokyo to Los Angeles.

37. ŻYLICZ, supra note 2, at 141 .

38. Id. 
many years. ${ }^{39}$ The most restrictive and most prevalent type of bilateral arrangement provides for limited market access usually with only one gateway, government authorization of pricing, and other strict controls on economic conditions and commercial operations. ${ }^{40}$

Other than the Chicago Convention, no substantial global effort toward an agreement on economic rights has been attempted. Several nations have tried to initiate discussions only to be rebuffed by many of the major air powers. ${ }^{41}$ The only successful multilateral endeavors have been those that are limited in scope. Agreements have been signed that address mostly soft rights "that affect the operation of civil aircraft, such as overflight rights, nationality of aircraft, and minimum safety, maimtenance, and training standards." ${ }^{42}$

Recent legal developments in international trade and aviation pohicy, however, demonstrate a trend toward multilaterahsm. The General Agreement on Trade in Services (GATS) and its accompanying Annex on Air Transport Services (Annex) represent the most prominent steps toward more open skies under a multilateral trade agreement. Concluded as part of the General Agreenent on Tariffs and Trade (GATT) Urnguay Round in 1994, the GATS and its sectoral annexes ${ }^{43}$ either have been or are in the process of being approved by GATT members. The GATS apphies many of the GATT concepts, such as national treatment and most-favored nation status, to trade in such services as banking and transport. ${ }^{44}$ The air transport annex, however, limits the application of GATS to the following services: (1) aircraft repair and inamtenance; (2) the selling and marketing of air transport services; and (3) coinputer reservation system (CRS) services. ${ }^{45}$ At this time, GATS specifically excludes traffic rights and any services related

39. KASPER, supra note 15 , at 51-54.

40. ŻYICZ, supra note 2 , at 141.

41. KASPER, supra note 15 , at 56-57.

42. Id. at 45 .

43. Annexes are industry-specific attachments to the GATT and GATS agreements that set forth specific information relevant to that industry. They are incorporated fully into the obligations of GATT and GATS.

44. The Final Act Embodying the Results of the Uruguay Round of Trade Negotiations, Annex 1B: General Agreement on Trade in Services, (April 15, 1994) (33 I.L.M. 1125, 1167) [hereinafter Final Act]. For a further discussion of GATS and its application to international aviation, see infra Section $V(A)$.

45. Id., Annex on Air Transport Services, at 1188. 
to traffic rights. ${ }^{46}$ The Annex, however, does include a provision obhigating the parties to review the agreement at least every five years for possible expansion of its coverage. ${ }^{47}$

A number of regional groups have embarked upon other smaller, but more ambitious, multilateral accords. In 1991, the Audean Pact nations (Bohvia, Peru, Ecuador, Colombia and Venezuela) concluded an air transport treaty granting all five freedoms to each nation within the region. ${ }^{48}$ Moreover, near the end of 1994, a "Single Aviation Market" emerged between Australia and New Zealand so that "no constraints" would be imposed upon the operations of either nation's airlines in service to, from, or within the other's territory ${ }^{49}$ In addition, other regional economic organizations, most notably the European Urion, have taken small steps down the path toward multilateral air traffic rights, and the potential exists for further developinent within these groups. ${ }^{50}$

These movements toward multilaterahism appear at a crossroads for international aviation law and policy. The patchwork of bilateral agreements between countries has created substantial barriers to trade in international air transport. Nations are free to negotiate any level of liberalization in air services, and mevitably, protectionist influences creep into the process. The impediments to free trade take several forms, ranging froin overt acts, such as restricted landing rights or state subsidies of national airlines, to more subtle discrimination against foreign competitors, such as the imposition of burdensome domestic regulatory systems. ${ }^{51}$ Smallscale inultilateralism, however, points to the future of international air services agreements and highlights the need for change both in the approach and structure of the legal framework governing traffic rights.

46. Id.

47. $I d$.

48. Integration of Air Transportation in the Andean Subregion, May 16, 1991, 30 I.L.M. 1303, 1306 [hereinafter Andean Pact]. For an extended discussion of this accord, see infra Sectiou V(A).

49. Peter Harbison, Aviation Multilateralism in the Asia Pacific Region: Regulatory and Industry Pressures for Change, 19 AIR \& SPACE L. 138, 144 (1994).

50. See ŻYLICZ, supra note 2, at 109-33.

51. ECONOMiC EFFECTS, supra note 32 , at $* 18$. 


\section{THE JUSTIFICATIONS FOR THE PREVAILING BILATERAL SYSTEM}

The bilateral system rests on a foundation built upon five justifications. First and most importantly, the system draws much of its strength from its status quo position. As with any governmental function, the status quo possesses inertial force and changing it can be a difficult and drawn-out process because the current systein often embraces cherished and commonly accepted rationales. Air transport regulation is no different. The bilateral approach has facilitated advances in aviation over the past fifty years and, according to a foreign airline official with direct responsibility for negotiations, has "long proved to be a flexible vehicle for progressive liberahisation among pairs of like-minded States." Bilateral agreements are based largely on the fundamental and long esteemed principles of state sovereignty and equahty of opportunity. ${ }^{53}$ These are the principles upon whicl 1 nations have built and based their airline industries, and a liberalization of trade in air services appears to threaten those interests.

Second, the bilateral system's conservatisin is a supposed strength. Many nations and industry officials adhere tightly to the current regime because they view bilaterahism as the only viable option for regulation. Some nations and industry officials perceive the multilateral alternative, involving nunierous nations with diverse goals and levels of development, as impractical, complicated, and time-consuming to negotiate. ${ }^{54}$ In the recent past, members of botll. the executive and legislative branches of the Umited States, one of the leading aviation powers, have expressed serious reservations concerning a multilateral agreement for international air services. One nember of Congress, seeing no need for any changes, stated: "The bilateral system, in short, works. The question today is: If it ain't broke, why fix it? Why trade the bilateral regime for a multilateral framework? Would aviation for the traveling public be better off under a inultilateral regime? I think

52. Proceedings of the ICAO World-wide Air Transport Colloquium, ICAO PUBLICATION ORDER No. WATC92, § 3.11, at 3 (1992) [hereinafter WATC92] (statement of Vijay Poonoosamy, Director of Legal and International Affairs, Air Mauritius); see also ŻYICZ, supra note 2, at 143.

53. Abeyratne, supra note 6 , at 10 .

54. Geoffrey Lipman, Multilateral Liberalisation-The Travel and Tourism Dimension, 19 AIR \& SPACE L. 152, 156 (1994). 
not." ${ }^{\text {} 55}$ Furthermore, one of the lead U.S. negotiators who had responsibility for the development of any type of multilateral treaty publicly stated that "it would be a mistake to supplant the current bilateral regime witl multilateral rules." ${ }^{956}$

Ironically, many of the United States' competitors raise a third justification: A multilateral agreenent might have negative effects on their own airlines' economic survival due to the strength of U.S. carriers. Bilateral accords liave sheltered many inefficient national airlines from the open nuarket. A multilateral exchange of traffic rights likely would loosen the bilateral restrictions that have long shielded many national airlines from inarket forces, and those countries "that are neither confident of their airlines' ability to survive unrestricted competition without any protection, nor prepared to leave that sector of services to be taken over by more efficient and successful foreign operators" have staunchly supported the continuation of the bilateral system. ${ }^{57}$ The chairman of Japan Airlines sounded this warning several years ago. He cautioned:

Most Asian countries, including Japan, are not in a position to accept the sort of "law of the jungle" competition in which, I am sure, the strong mega-carriers would be the only survivors iu control of the market and the consumer. I cannot think of any country which will allow the loss of their airline to excessive freedom of competition .... 58

Hence, national airlines, exerting their influence over their respective government's policies, help to bolster the bilateral system because they perceive the system as providing economic protection that ensures their survival.

As a fourtl defense of bilateral arrangenients, one scliolar has argued that a bilateral system, as opposed to a multilateral one, can better account for the wide-ranging sociopolitical, geographic,

55. Whether International Airline Services Should Be Included In the General Agreement on Tariffs and Trade (GATT): Hearing Before the Subcomm. on Aviation of the House Comm. on the Judiciary, 101st Cong., 1st Sess. 18 (1989) [hereinafter GATT-Airline Hearing] (statement of Rep. James L. Oberstar, Chairman).

56. Id. at 24 (statement of Richard B. Self, former Deputy Assistant U.S. Trade Representative).

57. ŻYLICZ, supra note 2, at 36-37.

58. WATC92, supra note 52, $\S 1.13$, at 4 (statement of Susumu Yamaji, Chairman, Japan Airlines). 
and ethnic differences between States and global regions. ${ }^{59}$ Finally, countries also point to potential pitfalls as yet another reason to shy away from multilateralism. They "fear that indirect national pohicy measures remaining outside such an agreement, would affect the agreement's fair implementation." 60 These indirect measures might imclude government purchasing restrictions, access to airport gates, and limited takeoff and landing slots.

The arguments, advantages, and fears offered to bolster the current bilateral system have the coinbimed effect of anchoring many nations' aviation regulatory regimes in a static existence. The position of the bilateral system as the status quo and entrenched approach is hardly a reason to designate it as a preferential system. In the aviation context alone, examples abound in which nations have departed radically from the status quo in their regulatory frameworks. ${ }^{61}$ Moreover, the ability of a inultilateral agreement, as 'opposed to a bilateral agreeinent, to be more all-encompassing of the vast differences between States has not been tested adequately in the last fifty years since the conclusion of the Chicago Convention. Rather, the real justification for bilateralism rests on national fears of the direct and collateral consequences of open airline competition on doinestic carriers. This alleged justification, however, is merely a thin veil for protectionism.

\section{PRETEXTS FOR PROTECTIONISM}

The fear of unrestricted competition, which favors the prevailing bilateral system, subtly einploys the tempting theines of national security and national prestige. For lawmakers in numerous countries, these themes prove to be an attractive option upon which to base protectionist measures for their national airlines. Yet national security and prestige are no more legitimate a basis for protection of airlines than they were for another industry that once argued for special measures because of its unique national importance-steel.

59. Wassenbergh, supra note 6 , at 177.

60. ŻYLICZ, supra note 2, at 28.

61. See infra text accompanying notes 168-77 concerning the Andean Pact decision. Also, the United States' deregulation of the domestic airline industry in the early 1980 s stands as a prime example of how strong moves away from the status quo can be accomplished successfully. See ETHAN WEISMAN, TRADE IN SERVICES AND IMPERFECT COMPETTIION: APPLICATION TO INTERNATIONAL AVIATION 17-25 (1990). 
The steel industry, although a manufacturing industry, is analogous to the airline industry, a service industry, in several ways. First, both industries have an impact on national security interests, but not to the extent that some observers would claim. ${ }^{62}$ Second, both industries have operated at times under close government supervision as well as in a more deregulated market. Finally, steel and air transport have potential ripple effects on many other industrial and economic sectors.

In the late 1960s and early 1970s, inuch debate took place in the United States on the issue of foreign imports of steel and their possible effect on the large domestic steel industry. Steel industry executives pressed Congress for import quotas and other trade barriers to lessen the flow of imported steel into the United States. They achieved sonie ineasure of success with arguments that

[i]f the United States would rely more and more on importing steel, it would gamble with the national welfare and the national security by assuming that these imports would always be available in the future. We probably can afford to take this risk on Scotch whisky ... but we cannot allow a basic industry like the steel industry to decay. ${ }^{63}$

Congressional representatives took these statements at face value and worried about "the serious threat to national security" posed by foreign steel imports that might prevent the doinestic steel industry from being able to supply the country's needs in time of war. $^{64}$

These exaggerated fears, presented by the steel industry and gladly accepted by lawmakers, fed on one another to exalt steel to the status of a "unique" industry. Asked to give a reason why steel should be treated differently than other goods, one industry official responded,

Mr. Congressman, I certainly do believe that the steel industry has a unique case to present because steel, unlike many other

62. See infra notes 67-72 and accompanying text.

63. Foreign Trade and Tariff Proposals: Hearings Before the House Comm. on Ways and Means, 90th Cong., 2d Sess. 1867 (1968) [heremafter Foreign Trade Hearings] (statement of Thomas F. Patton, Chairman, Republic Steel Corp.).

64. See id. at 1829 (statement of Rep. G. Robert Watkins); Tariff and Trade Proposals: Hearings Before the House Comm. on Ways and Means, 91st Cong., 2d Sess. 1750 (1970) (statemeut of Rep. Tom Bevill). 
products, is a very basic material, basic to the welfare of the whole economy of the Nation, basic to the security of the Nation, and the country just can't get along without a healthy steel industry . . . . ${ }^{65}$

Such distinctions about the steel industry gave rise to even grander declarations about "American industrial capacity" serving as a "cornerstone of our national greatness," allowing legislators to espouse their support for free trade in theory but to employ trade barriers in practice. ${ }^{66}$

Yet the claim that national security and domestic steel production were intertwined rings hollow under closer examination. Upon direct questioning about the national security issue by one nember of Congress, a steel executive admitted that the proposed foreign steel quotas "would not be tied to national security as such. It would be a straight out quota bill, but it would have an impact on having steel available when national security requires it." ${ }^{\prime 67}$ If national security were truly the concern of the steel industry in its efforts to restrict imports, presumably its proposal would have addressed national security concerns. Instead, the industry opted for a "straight out quota bill" rather than a targeted solution aimed at potential security risks. Their underlying motivation seemed to be the protection of their economic position that was threatened by inore efficient foreign producers.

Likewise, international airlines, in inany countries including the United States, have sought to stabilize their positions in an increasingly competitive global inarketplace by playnig the trump cards of national security and prestige but keeping hidden their real agenda of protectiomsm. The current statements made by both legislators and the airline industry echo those nade during the steel debates twenty-five years earher. Once again, national security plays a major role in supporting the status quo and the protectionist bilateral system. At the same time, it also obscures the importance of addressing the practical issues involved in drafting and impleinenting a inultilateral agreenient for international air transport. On the issue of whether or not the United States should promote the inclusion of international air service under the GATS,

65. Foreign Trade Hearings, supra note 63, at 1906 (statement of Thomas F. Patton, Chairman, Republic Steel Corp.).

66. Id. at 1837 (statement of Rep. Edward J. Derwimski).

67. Id. at 1918 (statement of Thomas F. Patton, Chairman, Rcpublic Steel Corp.). 
one lawmaker counseled that he could "foresee national security implications. I can foresee other airlines coming in here ... and that would be a disincentive for our domestic airlines to do soine of the things we would like thein to do, to expand and also to be available when needed." 68

Air transport interest groups also have seized upon the national security issue as a means for justifying their opposition to a multilateral accord. National security, however, merely functions as a convenient pretext for economic protectionsm:

Finally, we beheve that placing the air transportation sector under GATS would ... result in a[n] . . . attack on our national defense. ... [B]ecause of the broad and immediate consequences of applying the national treatment principle to air transportation should that happen, the airlines froin the signatory GATS nations would receive, absent U.S. reservations, total access to U.S. skies. Froin a defense posture, we feel this is intolerable; froin an economic point of view, we believe that, opening up the richest aviation inarket in the world to all comers, in exchange for access, sonetimes limited, to national markets of all sizes, including the sinallest, would constitute a sweeping, unprecedented horse and rabbit trade. ${ }^{69}$

This statenient, although inentioning national defense, focuses primarily on the industry concern that it will lose its exclusive hold on the U.S. market and all the benefits associated with it. Again, national security is raised to shroud restrictive regulations on international air transport in the legitimate cloth of national defense.

Moreover, even if legitimate, the national security argument is a weak one at best to explain the reluctance of States and the industry to move toward a multilateral agreement. The Chicago Convention itself contains provisions dealing with national security and einergencies. In the event of a war or a national emergency, the Convention will not impinge on a nation's "freedoin of action" in using its civil air transport capabilities. ${ }^{70}$ Thus, countries' national defense interests are not compromised currently by the Chi-

68. GATT-Airline Hearing, supra note 55, at 35 (statement of Rep. Sherwood Boehlert).

69. Id. at 55 (statement of James E. Landry, Air Transport Association of America).

70. Chicago Convention, supra note 4 , art. 89 , at 356 . Presumably, this right would allow a nation to abrogate any of the provisions of the Convention if they interfered with the nation's defense capabilities in time of war or emergency. 
cago Convention, and a multilateral treaty is not likely to compromise them in the future. In addition, the few countries that might have actual national security uses for their civil aircraft still would be able to meet those requirements under any new multilateral regime, either based on the strength of those national airlines or on a specific condition ensuring the availability of aircraft for such purposes. ${ }^{71}$ Finally, a negotiator for the Uinted States in the GATT Uruguay Round has warned Congress about the danger of relying on national security as a trade pohicy foundation:

[N]ational security can be exploited, it can be a basis for protectionisn ... and I think we need to be careful on what basis we decide we're going to protect an industry. ... If we feel we have to protect an industry for any number of reasons, then I think we ought to go ahead and do so. But I frankly don't like the notion of excluding it on the basis of national security when you really can't nake a credible arguinent that that's the case. ${ }^{72}$

Thus, the national security argument is an improper basis for opposing a multilateral air transport agreement since no actual security issues are implicated.

Behind the rhetoric of national security lurks an ulterior concern about economics. Despite the implications of inaintaining protectionisin through the bilateral system, soine nnembers of Congress seenr wedded to the idea that if the bilateral system is abandoned "in favor of some international inultilateral regime ... you can kiss aviation goodbye in the same direction that steel went .... And there is no way that this committee is going to tolerate that.."73 Once again, the ineinories of the steel debate are invoked to remind those who support inultilateralisin of its alleged risks to an industry.

Although the United States did use protectioninst measures for the steel industry periodically over the past three decades as a ineans to shield the industry from the impact of foreign competition, those protectionist nieasures were unnecessary and yielded

71. See KASPER, supra note 15 , at 71 . The nations most likely to have these civil defense requirements are those with some of the strongest national airlines-including, among others, the Umited States, the Urited Kingdom, France, Canada and Japan. Id.

72. GATT-Airline Hearing, supra note 55, at 35 (statement of Richard B. Self, Deputy Assistant U.S. Trade Representative).

73. Id. at 56 (statement of Rep. James L. Oberstar, Chairman, House Subcomm. on Aviation). 
little benefit to the industry for its long-term improvement. Despite the breathing room given by tariffs and other import restraints, the industry did not take "'advantage of it to become competitive."'74 In fact, steel manufacturers did not use any of the additional income attributable to this protection to improve their equipinent and modernize their facilities in order to achieve sustained coinpetitiveness. ${ }^{75}$ Instead, management and labor did not face the difficult task of increasing efficiency and reducing industry costs until they faced "the shock of renewed foreign coinpetition when protection was temporarily lifted from the U.S. steel market, and the sustained coinpetition from efficient doinestic minimills."76 Hence, coinpetition, not protectiomism, spurred the renewed competitiveness of the American steel industry after years of overcapacity and inefficiency.

Legislators are not the only parties guilty of rehashing these old and discredited arguments in favor of protectiomism to rationalize their continued opposition to aviation multilateralism. Many airline representatives today are repeating the same arguments used at the 1948 session of the ICAO Commission on Multilateral Agreement on Commercial Rights in International Civil Air Transport. The national delegates to this ineeting rooted their objections to a innltilateral agreement in the primciples of national interest and especially, state sovereignty; these were primciples that the States had accepted as the baseline for the creation of any agreement. ${ }^{77}$ Most national delegations seemed interested only $\dot{m}$ denying hard rights to other nations, and sovereignty and national interest proved to be useful vehicles for this purpose. National interest evolved into the "duty" of States to protect their own

74. Paul Dwyer, Jr., Recent Developments, 26 HARV. INT'L L.J. 287, 293 (1985) (qnoting then U.S. Trade Representative William E. Brock).

75. Joel B. Dirlam \& Hans Mueller, Import Restraints and Reindustrialization: The Case of the U.S. Steel Industry, 14 CASE W. RES. J. INT'L L. 419, 427, 430-31 (1982); see also Note, Protecting Steel: Time for a New Approach, 96 HARV. L. REv. 866, 876-77 (1983).

76. Dirlam \& Mueller, supra note 75, at 434. But see Craig P. Seebald, Note, Life After the Voluntary Restraint Agreements: The Future of the U.S. Steel Industry, 25 GEO. WASH. J. INT'L L. \& ECON. 875, 905 (1992) (arguing that voluntary restraint agreements have been a contributing factor in helping the steel industry rebound economically).

77. See 2 Records of the Commission on Multilateral Agreement on Commercial Rights in International Air Transport pt. 2, at 321, ICAO Doc. 5230, A2-EC/10 (Apr. 1948) [hereinafter 2 Records pt. 2] (statement of D. Chakroverti, India). 
burgeoning aviation industries, ${ }^{78}$ even if that interest conflicted with multilateral ideals. Similarly, some nations employed sovereignty "to reserve the right to refuse to enter into a 'route agreement,' in the absence of which their territory remains closed, and to be able to refuse this agreement solely through the exercise of their severeignty [sic], without even having to give the reasons for the refusal." principles and the goals of a multilateral agreement, the delegates in 1948 were unable to conclude successfully an accord encompassing a multilateral exchange of economic rights. National sovereignty and interest had prevailed over more open trade, and this triumph has created a lasting legacy. Its effects still can be observed today.

Groups that staunchly resist any serious overtures toward a multilateral exchange of traffic rights draw on the fundainental tenets of sovereignty and national interest that were laid out almost fifty years ago. They use those ideas today, as well as national security and prestige, to defend their continuing protectionist practices, claiming that

national interest has led all countries-however small-to have their own airlines, be it to promote trade and tourism, provide national security or simply show the flag. ... The point is that national sovereignty and national pride are as relevant today as they were in 1944. And governments need airlines, almost as much as airlines need governinents. ${ }^{80}$

At first glance, the similarities between the past and current rhetoric for the bilateral system may seem irrelevant. Yet a deeper scrutiny of this rhetoric reveals that "bilateral air service agreenents have become rigid instruments for protecting the narrowly defined interests of national carriers." ${ }^{81}$ The recent and continuing financial troubles of Iberia, the Spanish national airline, illustrate these narrow national carrier interests.

Iberia still totters on the edge of bankruptcy despite years of government subsidies. ${ }^{82}$ After infusing almost one billion dollars

78. See 2 Records pt. 1, supra note 1, at 291 (statement of Dr. P. Cunha, Portugal).

79. 2 Records pt. 2, supra note 77, at 584-85 (statement of H. Bouché, France).

80. WATC92, supra note $52, \S 1.17$, at 5 (statement of Aruna Mascarenhas, Deputy Director for Planning and International Relations, Air India).

81. Id § 3.15, at 1 (statement of David Buckingham, First Assistant Secretary for Aviation, Australia).

82. Nathaniel C. Nash, The Struggle to Keep Iberia Aloft, N.Y. TIMES, Jan. 14, 1995, 
into Iberia three years ago, the Spanish government has proposed another aid package of one billion dollars for Iberia subject to European Union approval. ${ }^{83}$ Many of the difficulties that Iberia now faces, however, can be traced to its (as well as other national carriers) historical use as a "governmental employment agenc[y] and [an] expensive vehicle for waving the flag around the globe." ${ }^{94}$ In the particular case of Iberia, Spain tacitly niay have approved of Iberia's significant investments in many South American carriers because of the control it gave Iberia over the air transportation routes of former Spanish colonies. ${ }^{85}$ Yet these investments, if not poor ones from the start, were managed improperly and operated not with the intention to turn a profit but instead to "wave the fiag." Hence, Iberia and the Spanish government used each other to accomplish their goals but the means of donig so were less thau optimal for either a solid business plan or astute foreign policy.

Iberia's situation highlights the trouble caused when airlines and governmeuts become too dependent on one another. Despite the rhetoric to the contrary, ${ }^{87}$ this dependence inay not necessarily be healthy for airlines, or their governments that feel the need to subsidize their flag carriers. The bilateral system allows governinents to avoid jeopardizing their national interest and pride in their flag carriers by protecting thein from the greater competition likely to occur in a inore liberalized regulatory regime. Rather than face the economic reahities of inefficient national airlines, governments rely on the bilateral systein to inisulate those airlines from the inarket. The consequences of these attitudes are evident in the present day aviation regulatory system.

Nations have wrapped their bilateral agreements around the sovereignty of their airspace, ${ }^{88}$ and negotiations have resulted in more protectionisin because "the sovereignty regime miphes re-

at 21 .

83. Id.

84. Id.

85. Id. at 31. Iberia acquired controlling interest in Aerolineas Argentinas, Ladeco, and Viasa; these are, repectively, the national airlines of Argentina, Chile, and Venezuela. Id.

86. See id.

87. See supra note 80 and accompanying text.

88. Bruce Stockfish, Opening Closed Skies: The Prospects for Further Liberalization of Trade in International Air Transport Services, 57 J. AIR L. \& CoM. 599, 639 (1992). 
striction and thus remains the mam legal obstacle to a free and rational development of international air navigation and trade." 89 The impact of the rhetoric opposing multilaterahism, however, is not limited merely to the pohicymaking realm. Upon closer inspection, nations and representatives of the airline industry are violating at least the spirit of several international accords by contimuing to resist serious discussion of the best inethods to achieve a multilateral agreeinent. ${ }^{90}$

Nations did not intend for bilateral agreements to become the permanent instruments of international aviation regulation. Declarations of some speakers from the 1948 ineeting on a inultilateral accord support the view that bilateralism was intended to be an interim stage in the process of reaching a multilateral accord, which the negotiators considered to be their ultimate goal. ${ }^{91}$ Yet the present vigor and intensity with which many nations, most airline officials, and several interest groups resist a inultilateral treaty create the risk of running afoul of this understanding reached at the 1948 ineeting. Indeed, when the delegates to the 1948 meeting failed to reach their goal of a multilateral treaty, one delegate worried that the group had not met the expectations of the framers of the Chicago Convention because "the underlying dogma of the Chicago Convention ... I should say the contractual obligation of co-operation, both economic and political, between the

89. ŻYLICZ, supra note 2 , at 62 .

90. The recently concluded 1994 World-Wide Air Transport Confereuce manifested this resistance to a serious discussion of multilateralism. The delegates to the Conference did explore some options for multilateralism, but quickly tabled these ideas as ill-suited for the preseut state of international civil aviation. Report of the World-Wide Air Transport Conference, ICAO Pub. No. 9644, AT Conf/4, 53-54 (Nov.-Dec. 1994) [heremafter ICAO Conference 94]. The delegates reaffirmed their commitment to the existing bilateral system and its core concepts as well as the right of "direct, meaningful aud sustained participation by all States in the international air transport system." Id. at 11. Such devoted attachment to these principles is at odds with progress toward a multilateral agreement. In fact, the Conference disregarded the view expressed by one delegate in support of open and "vigorous" competition. Id. at 19. Rather, the Confereuce refused to condemn such auticompetitive practices as state subsidies to airlines as inherently unfair and instead recognized them as a necessary tool for some governments and their carriers. Id. at 28. To be fair, the Conference did acknowledge that regional liberalization or multilateral agreements could be instructive for the future, but the delegates made no commitments moving their countries or airlines in this direction. Id. at 54.

91. See 2 Records pt. 1, supra note 1, at 40 (statement of W.C.G. Cribbett, United Kingdom); 2 Records pt. 2, supra note 77 , at 578 (statement of G. Norton, United States). 
Member States of ICAO" had not been achieved. ${ }^{92}$ Nonetheless, the bilateral system has continued for more than fifty years and has been the only widely recognized system in the world during that time. Given the relatively short period of time in which commercial aviation has existed, the bilateral system seems to be becoming a pernanent fixture of national regulation. This present development runs contrary to the wishes of the many nations that signed the Chicago Convention with the vision that a mnltilateral regime would soon take hold in international air transport.

Furthernore, the language of the Convention itself supports this multilateral perspective. The Preamble to the Convention states that the contracting States undertook the provisions in order that "international air transport services" could be "operated soundly and economically." ${ }^{\prime 93}$ Although the Convention makes no specific mention of the methods in which air transport services should be operated in order to be sound and economical, a strong argument can be made that the bilateral system does not accomphsh this objective efficiently or optimally. The nature of bilateralism runs counter to the growth demanded by the market for international air services, and multilaterahism is better situated to accommodate and assist the changing needs of aviation. ${ }^{94}$

The Convention also covered the potential development of multilateral air transport operations. For example, Article 77 states that any number of contractimg States, without violating the Convention, may combime their air services or routes and establish any organization to oversee this process. ${ }^{95}$ Though the Convention stops short of explicitly fostering such multilateral groupings, its language avoids placing any additional obstacles to their creation. Thus, nations and industry cannot claim legitimately that the Convention limits their ability to pursue a multilateral agreement. In fact, any invocation of the Chicago Convention as a basis for refusing to consider multilateralism inay violate the signatories' goal of sound and economic airline operation.

\footnotetext{
92. 2 Records pt. 2, supra note 77 , at 586 (statement of $\mathrm{H}$. Bouché, France).

93. Chicago Convention, supra note 4 , pmbl. at 296.

94. See supra text accompanying notes $9-14$; see infra text accompanying notes $102-06$.

95. Chicago Convention, supra note 4 , art. 77 , at 348.
} 
In addition, the GATS, ${ }^{96}$ a recently adopted multilateral agreement from the 1994 completion of the GATT Uruguay Round, contains commitments by its contracting parties pertaining to air transport. As part of the gradual move toward liberalization in trade of services, signatory nations agreed to allow the Council for Trade in Services to review periodically the Annex on Air Transport Services with a view toward its expansion into other areas of the aviation sector. ${ }^{97}$ Certainly, the great reluctance expressed by many nations and airlines to further utilize multilateral accords in this industry does hittle to advance this obligation. Indeed, their unwillingness to even broach the subject-let alone to help work out the details-of a multilateral exchange of commercial aviation rights may place them in violation of their contractual duties under the GATS. Of course, no nation or its national airlines will be penalized for these potential breaches of duty under either the Chicago Convention or the GATS. Nevertheless, these breaclies undermine the confidence and stability of the contracting States to enter into a more liberal phase of international aviation regulation. As a consequence, doubts still plague the discussion about the best means, if any, to einploy in reshaping the international aviation regulatory landscape.

\section{THE Merits of a Multilateral System}

Economics, efficiency, and necessity justify support for a inultilateral agreement as opposed to contimued use of the bilateral system. These three justifications can have far-reaching results for the imdustry and the airlines' home countries.

The primary reason for a multilateral approach rests on economic grounds. The changing and interdependent nature of the current global marketplace has outstripped the ability of the bilateral system to accommodate those changes and therefore has left

96. Final Act, supra note 44.

97. Final Act, supra note 44, Annex on Air Transport Services, at 1188. Although the Annex on Air Transport Services specifically exempts traffic rights and their related concerns, that exemption likely does not apply to the cited provision regarding review of the agreement for potentially wider application of its commitments. If it did, then the periodic review provision would have little or no effect. Although the GATS and the Annex could be used to liberalize other soft rights in aviation, the largest area for expansion of its free trade principles is in lhard rights or traffic rights. Traditional legal interpretation requires that an agreement should not be interpreted, if at all possible, to make any obligation irrelevant. 
airlines "increasingly unable to function efficiently without full commercial freedoon." 98 The effect of these bilateral limitations on the economic potential of airlines can be seen most clearly in the United States. The United States possesses one of the largest and most competitive airline markets and traditionally pursues avenues for the industry to expand internationally. Even a nuarketoriented nation such as the United States, however, has outgrown the usefulness of bilateral agreements as liberalizing trade vehicles; U.S. carriers can obtain continued progress in opening international routes only through multilateralisin. ${ }^{99}$.

In fact, several nations are starting to accept the proposition that bilateral agreements actually may be hindering rather than helping their national airlines. These countries "have begun to support increased liberalization not necessarily because they beheve in its virtues, but because they view liberalization as essential to the viability of their airlines in an mcreasingly coinpetitive marketplace." ${ }^{100}$ The United States is one of the countries supporting this viewpoint. A national study conducted of the U.S. airline industry concluded that "bilateral agreeinents cannot adequately protect or enhance US interests and that continued rehance on that approach will erode those interests ... Bilateral negotiations have become an exercise in zero-sum market division."

Instead, the air transport system could capitalize on several economic advantages likely to follow the liberalization of trade in air services. These advantages would include overall gains in international air traffic as well as the "optimization" of the route system through improvements in patterns, schedules, fares, capacities, and frequencies. ${ }^{102}$ In economic terms, international aviation services can be characterized as "economies of scope."103 Multilater-

98. Lipman, supra note 54 , at 153.

99. KASPER, supra note 15 , at 90.

100. Id. at 1-2.

101. Michael Goldman \& Cyril Murphy, Multilateral Age Approaches; International Aviation Agreements Shift From Bilateral to Multilateral Strategies, AIRLINE BUS., Feb. 1994, at 44, 45 (quoting The National Commission to Ensure A Strong Competitive Airline Industry).

102. See ŻYLICZ, supra note 2, at 36 .

103. WEISMAN, supra note 61, at 36-37. Economies of scope occur when the costs of producing two or more services or products using an indivisible but shareable input are less than they would be if each service or product were produced separately. Id. at 32 . In the aviation context, this involves the "hub and spoke" concept in which passengers are brought together from separate spokes to one central location, the hub. Id. at 33 . 
alism in air transport would allow airlines to take advantage of these economies of scope through expanded route networks as well as imcreased capacities and frequencies on existing routes. ${ }^{104}$ Empirical studies have demonstrated that when airlines can offer greater access to destinations, which can be achieved best through a multilateral framework, they imcrease the number of passengers per aircraft, which lowers the fixed costs of such items as the aircraft itself, jet fuel, and airport facilities. ${ }^{105}$ Therefore, airlimes can provide their services more efficiently and clieaply while imcreasing the total amount of passengers carried. ${ }^{106}$ Ironically then, the supposed justification for bilateralism-protection of national airline economic markets-is better served under a multilateral framework.

A handful of industry executives has foreseen these potential gaims and embraced multilateralism. Supporters of these views, led by Singapore Airlines, have sought to demonstrate the advantages of a multilateral system to both large and sinall nations. Under a multilateral system, sinall nations would be able to service larger narkets without the implied requirement of offering access to a market of equal size in return. ${ }^{107}$ At the same time, larger nations and their airlines could expand into multiple sinaller markets quickly and easily. ${ }^{108}$ Although the overall economic advantages of a multilateral system are the most visible improvements, the disinantling of the bilateral system also would produce other benefits for the interested parties, both large and small.

From an efficiency standpoint, the nature of a bilateral negotiation and agreement hampers the advancement of international air transport. The number of bilateral agreements in existence-approximately 2,000 -inposes unnecessary burdens on government resources by forcing countries to negotiate and supervise compliance witl a wide array of restrictions. ${ }^{109}$ The bilateral system also lacks uniformity of regulation, causing airlines to spend extra

\footnotetext{
They then can be carried more cheaply on international routes by one aircraft departing from the hub rather than several separate aircraft making the same trip from individual spokes.

104. Id. at $37-38$.

105. Id. at $36-37$.

106. Id. at 3 .

107. WATC92, supra note 52, § 2.13, at 4 (statement of Matthew Samuel, Director of Corporate Affairs, Singapore Airlines).

108. Id.

109. Lipınan, supra note 54, at 153.
} 
time and money in an attempt to comply with their differing and unequal requirements. ${ }^{110}$ These limitations and obstacles taken together lead to mefficiencies in both airline operations and government regulatory schemes thereby reducing the public's maximum access to air travel.

Necessity is a third factor that dictates changes im the legal framework governing the grant of hard rights im aviation. The quid pro quo exchange common to bilateral accords "tends to reduce the availability of new service opportunities to the level acceptable to the least competitive airline, and [therefore to] the most protectionist stage." 111 Hence, routes and capacities are not free to develop even if the market can sustain them, ${ }^{112}$ and air services fail to reach the growing portion of the world population that desires to use them. This failure to reach populations in need of air services will be exacerbated if the forecasts of rapid passenger growth come to fruition in the next decade, ${ }^{113}$ largely because this break in service will represent a significant missed opportunity for airlines in desperate need of new markets.

A multilateral exchange of imternational air traffic rights can avert these bilateral deficiencies. Passengers would gam from increased flight schedules and new routes served by airlines. The airlines, in turn, also would benefit by being able to tap into new markets with an increasing pool of customers from which to draw. Finally, nations, although perhaps losing some of their negotiating leverage in a multilateral agreement, would profit by being able to disinantle much of the large regulatory structure surrounding international air traffic riglits, thereby saving the political and economic capital of governments.

In 1948, the delegates confronted two options concerning aviation regulation. One option would have taken the contracting nations im the direction of a multilateral agreement. For various reasons mainly relating to the refusal of countries to sacrifice any of their rights associated with international air transport, this option did not materialize, and restrictions were placed on trade. ${ }^{114}$ Instead, the second option, bilateralism, developed into the driving

110. ŻYLICZ, supra note 2, at 143.

111. Lipman, supra note 54 , at 153 .

112. Id.

113. See supra notes $9-10$ and accompanying text.

114. See supra text accompanying notes 77-79. 
force in aviation regulation. At that time, one delegate realized "that by relying completely and totally on bilateral negotiations of routes you are making an end in itself of bilateralism rather than the multilaterahsm whicl should be our goal."115 Given the current stage of development in international aviation regulation, this prediction may have come true. The dangers of bilateralism as an end in itself now threaten the future ability of nations and their airlines to provide their service effectively and efficiently to the inarket. ${ }^{116}$ The future of multilateralism, however, has reached another turning point. Almost fifty years after the failure to establish a multilateral regime, States and the industry have another chance to secure the benefits of a multilateral agreement for trade in international air service for themselves and for the public.

\section{Methods to AdVANCE the Debate}

\section{A. Optimization of Public Service and Sectoral Balance}

The controversy regarding a multilateral aviation trade pact has centered on the necessity of such an agreement. Many nations and their airline industries claim that the burdens of multilateralism would be too great to make the benefits worth pursuing and that the bilateral systein serves them well. This difference in outlook among the various aviation imterests does not bode well for progress toward multilaterahism because "the lesson is clear: as long as our work does not rest on common political ground, success will remain most improbable." ${ }^{\text {"117 }}$ At this poimt, it bears repeating that multilateralism should be the common political goal of the players engaged in the debate. Though a multilateral agreement is not a panacea for the ills of the current aviation legal framework, it does hold the most promise as a vehicle to facilitate the future growth of international air services. This promise, however, can be realized ouly if the parties agree to work together to solve the potential pitfalls of any new legal system.

Yet the ouly common ground that the two sides share seems to be the zeal with which each pursues its own narrow self-imterest. The thinking and approach of nations is still mired in the

115. 2 Records pt. 1, supra note 1, at 39 (statement of J. Baldwin, Canada).

116. See supra notes 98-101, 109-113.

117. 2 Records pt. 2, supra note 77, at 587 (statement of H. Bouche, France). 
traditional bilateral structure of "mercantilism and reciprocity"118 in which no exchange is made on one side without an even exchange in return. The task, therefore, requires convincing the various States, airlines, and other affected groups to lay down their negotiating weapons and to open their eyes to the possibilities of a new legal structure for international air transport. ${ }^{119}$ Such a task, however, will neither be easy nor simple.

A good starting point for a multilateral pact would be a collective policy goal for international aviation. For example, one possibility is the "optimization of public services,"120 under which States would leelp their airlines serve more passengers by giving them access to more destmations. ${ }^{121}$ This desire for optimization is common to all nations. ${ }^{122}$ A multilateral agreement exchanging commercial traffic rights would advance this goal because it would increase the number of routes and destinations that a nation's airlines could serve. In addition, such an approach would expand capacity levels so that inore passengers could have access to those flights.

The recently concluded bilateral "open-skies" treaty between the United States and Canada serves as a perfect example of how liberalization can increase the availability of routes and flight frequencies. In February 1995, the Umited States and Canada signed one of the most hiberal bilateral air services agreements in the world. ${ }^{123}$ The agreement granted both of Canada's national airlines, Air Canada and Canadian Airlines International, the unfettered right to serve any city in the Umited States from any city in Canada. ${ }^{124}$ In return, U.S. airlines received unlimited rights to serve all Canadian cities from all points within the United States;

118. Harbison, supra note 49 , at 141.

119. Id.

120. ŻYLicZ, supra note 2, at 189.

121. Id.; WATC92, supra note 52, $\$ 3.2$, at 3 (statement of Vijay Poonoosamy, Director, Legal and International Affairs, Air Mauritius).

122. ŻYLICZ, supra note 2, at 189.

123. See Clyde H. Famsworth, U.S.-Canada Pact Ends Restrictions on Air Travel, N.Y. TIMES, Feb. 25, 1995, at A1. Although the two countries achieved much liberalization through a bilateral agreement, this fact sliould not be interpreted to mean that bilateral agreements still can be effective vehicles for long-term global liberalization. See supra notes 98-101 and accompanying text. Rather, this bilateral agreement demonstrates the potential advantages to be gained by the countries of the world through such liberalization on a global scale.

124. Craig Turner, Pact to Expand Air Travel Caps Clinton Canada Visit, L.A. TIMES, Feb. 25, 1995, at A1. 
however, U.S. airlines' access to the three major Canadian hubs, Vancouver, Montreal, and Toronto, will be phased in over an adjustment period of two years for Vancouver and Montreal and three years for Toronto. ${ }^{125}$

Almost immediately after the conclusion of the agreement, both Canadian and U.S. airlines announced plans for new routes. For example, Northwest airlines began connecting Ottawa and Halifax with Detroit, as well as connecting Regina, Calgary, and Saskatoon with Minneapolis. ${ }^{26}$ These were all previously unavailable services. Likewise, Air Canada has plans for twenty new U.S.Canadian routes, many of which will be nonstop direct flights to cities that previously could be reached only by making connections. ${ }^{127}$ In fact, Air Canada already has begnn direct, nonstop service between Ottawa and Washington, D.C. ${ }^{128}$ Hence, the travelling public now can reach more destinations im Canada and the United States in less tine.

Moreover, nations and airlines would benefit from multilateralism because increased international traffic would add to the value of export services and reduce the cost of importing foreign airline services, thereby creating "a doubly beneficial effect on the national balance of payments." 129 This advantage, lowever, is a mixed blessing because foreign airlines also would be competing for the same passengers im certam markets, which would cause exports to decrease and inports to rise. ${ }^{130}$ The question then becomes whicl nations, based on the size and strength of their market and airlines, will be net exporters or inporters of international air transport. The answer to this question, however, risks dividing the parties once agam and setting thein against eacl other in a zero-sum struggle for traffic rights.

A tactic to overcome this potential divisiveness may lie instead in the idea of sectoral balance. Sectoral balance refers to the

125. Id.; Farnsworth, supra note 123 , at 5 .

126. Louise Kinross, Open Skies Could Take the Hassle Out of Flying, Fin. POST, Apr. 19, 1995, at 24.

127. Id.

128. Id.

129. ŻYLICZ, supra note 2, at 6. Again, the U.S.-Canadian bilateral agreement is instructive on this point. According to the United States Airports for Better International Air Service, the new accord should result in a $\$ 15$ billion annual mcrease in trade and tourism on both sides of the border as well as create 290,000 new jobs. Farnsworth, supra note 123 , at 5 .

130. ŻYLICZ, supra note 2 , at 6 . 
concept of an overall balance in the exchange of rights but eschews the need for exact reciprocity, either in the nature of the rights exchanged or among the countries doing the exchange. ${ }^{131}$ Sectoral balance in the air services context could be struck between developed and developing countries. Developed countries would agree to allow greater access to their inarkets for developing nations' airlines regardless of the size of the inarket gained in return, and would guarantee a minimum traffic share for the weaker airlines. ${ }^{132}$ In return, developing nations also would hberalize access to their markets as well as other regulations, like capacity and pricing provisions, which are characteristically more restrictive in less developed nations. ${ }^{133}$ This tactic would give developing airlines the access and support they need to serve new destinations effectively while allowing developed airlines the ability to expand their operations into new routes. ${ }^{134}$

Many developing nations, however, express fear that stronger carriers from developed nations will drive their airlines out of business through stronger route networks, greater frequencies and capacities, and other benefits ranging from frequent flier programs to computer reservation systems. ${ }^{135}$ Thus, developing nations would be left without their own imdependent ineans of international civil air transport. Consequently, many countries would prefer to have their own airlines for self-reliance and nationality reasons, and not becoine dependent on foreign providers.

These potential criticisms of any multilateral approach to regulating international air transport can be answered. First, any inultilateral approach that eventually is chosen is unlikely to be an immediate and coinplete global solution. Accommodations will have to be made for developing nations and their inarkets to adjust gradually to new economic realities. ${ }^{136}$ Furthermore, according to a representative from a devoloping nation's airline, inost

131. See Harbison, supra note 49, at 145; see also ŻYLICZ, supra note 2 , at 189.

132. ŻYLICZ, supra note 2, at 199-200.

133. Id.

134. Id. at 200 .

135. See WATC92, supra note 52, $\S 1.17$, at 2 (statement of Aruna Mascarenhas, Deputy Director of Planning and International Relations, Air India).

136. Id. § 2.13, at 5 (statement of Mathew Samuel, Director, Corporate Affairs, Singapore Airlines Limited). Even staunch advocates for multilateralism, such as Mr. Samuel, are willing to recognize that developing nations may need special treatment for a limited period of time. 
countries' airlines under a multilateral legal system would be able to survive as niche market carriers, possibly feedimg passengers to larger carriers for other routes. ${ }^{137}$ In fact, if a nation's airline eventually ceased operations under a multilateral framework, that nation still would have air transport services linking it with other geographic areas because industry and service providers seek markets that are underserved. ${ }^{138}$

In addition, developing nations may have a long-term reason to support multilateral efforts. A multilateral air transport regime could open developing countries to mcreased air service by foreign providers, thereby resulting in greater economic development because "[e]conomies can only grow in places that are accessible in physical terms. ... [And] the speed at which a region develops is directly counected to the efficiency of its transport system, and of its air transport in particular."139 Hence, developing countries, at the very least, can maintain their own national airlines in the short term under a multilateral regulatory framework and potentially can achieve real economic benefits and growth in the long-term.

Hence, a productive tactic for encouraging States and industry officials to accept the challenge of fashioning a hberal but fair multilateral agreement moves the debate away from the sovereignty and protectionist-centered attitudes of the past to an approach entphasizing public service and sectoral balance. States, functioning in the best interests of their citizenry, can adopt as their goal the maximization of air service levels for the public. In addition, to avoid any potential unfairness or inequalities that might come witl such a goal, countries could agree to an overall sectoral balance of rights under which States exchange one type of right in return for a different but equally valuable right. By using this inethod, the parties can find the "common political ground"140 necessary to advance toward a multilateral legal framework for air transport.

As mentioned earlier, however, nrany practical obstacles stand in the way of the conclusion of a inultilateral agreement. One of the primcipal obstacles will be the demands placed upon any multilateral instrument by the various interest groups affected because

137. See id. $\S 1.17$, at 3 (statement of Aruna Mascarenhas, Deputy Director of Planning and International Relations, Air India).

138. See id. $\S 4.13$, at 2 (statement of Otto Loepfe, President, Swissair).

139. Id $\S 4.13$, at 1 (statement of Otto Loepfe, President, Swissair).

140. 2 Records pt. 2, supra note 77, at 587 (statement of Henri Bouché, France) (emphasis omitted). 
further efforts to negotiate liberalized trade in air services ... must be able to satisfy consumers, airlines, labor, and governments, all of whom ask "What's in it for us?" This will not be an easy task for a mature industry accustomed to receiving substantial protection from the rigors of competition. Nor will it be easy to convince privately owned airlines that a GATT-type regime can ensure fair competition with foreign airlines that are extensions of their national governments. Finally, neither governunents accustomed to exerting significant control over their nations' airlines nor a labor force shielded by airline regulation can be expected to embrace liberalizing changes that weaken their present positions. ${ }^{141}$

Countries have utilized several methods im an effort to satisfy these demands. Although these efforts at liberalization have not existed long enough to evaluate their effects, they can be analyzed for their potential ability to fulfill the parties' requirements and to achieve more open trade in air transport.

The broadest effort aimed at trade liberalization of international air services is the GATS and its aviation sectoral Annex. ${ }^{142}$ The Annex covers both scheduled and nonscheduled commercial air traffic as well as any related ancillary services. ${ }^{143}$ Furthermore, the Annex specifies that traffic rights ${ }^{144}$ are excluded from the application of GATS measures. ${ }^{145}$ Only aircraft repair and maintenance, air transport marketing and sales, and computer reservation services are subject to the GATS requirements and

141. KASPER, supra note 15 , at 113-14.

142. For extended treatments on the specific provisions of the GATS and its application to international air transport services, see ŻYLICZ, supra note 2, at 178-83; Zebinsky, supra note 33. See also Jeffrey R. Platt, The Creation of a Community Cabotage Area in the European Community and its Implications for the US Bilateral Aviation System, 17 AIR \& SPACE L. 183, 193-98 (1992).

143. Final Act, supra note 44, Annex on Air Transport Services, at 1188.

144. Traffic rights are defined as

the right for scheduled and non-scleduled services to operate and/or to carry passengers, cargo and mail for remuneration or hire from, to, within, or over the territory of a Menber, including points to be served, routes to be operated, types of traffic to be carried, capacity to be provided, tariffs to be charged and their conditions, and criteria for designation of airlines, including such criteria as number, ownership, and control.

Id. at 1189.

This definition is somewhat broader than that used in this Note. The GATS definition of traffic rights, however, fits the broader category of hard rights in aviation.

145. Id. at 1188 . 
principles. $^{146}$ Of these requirements and principles, three are most pertinent to aviation: (1) Most Favored Nation; (2) national treatment; and (3) inarket access.

The Most Favored Nation clause (MFN), ${ }^{147}$ a provision carried over from the GATT, would require that the allowances and freedoins given by one nation to another in an aviation treaty would have to be given to all other nations who are signatories to the GATS. ${ }^{148}$ National treatment dictates that a country treat foreign service providers no differently than it treats its own domestic service industry with respect to any regulations or laws that affect the delivery of that service. ${ }^{149}$ Market access is a companion principle to national treatment, and it requires that contracting States gradually remove the barriers to entry into a market according to an agreed upon schedule. ${ }^{150}$ In addition, only the MFN provision applies uniformly to all the signatories, whereas the national treatment and market access clauses are limited to the "conditions and qualifications"151 establislied by the Parties in the Agreement itself. ${ }^{152}$

Scholars and industry officials have criticized strongly the GATS method of trade liberalization more for its prospective application to hard riglits than for its current use with soft rights. ${ }^{153}$ First, the GATS conflicts witl some of the basic principles of the Chicago Convention. ${ }^{154}$ Most notably, the MFN clause appears to undermine the right of exclusive sovereignty that eacl State possesses according to Article I of the Convention ${ }^{155}$ be-

146. Id.

147. Id at 1169 .

148. Abeyratne, supra note 6 , at 29.

149. Zebinsky, supra note 33, at 377.

150. Id.

151. These conditions and qualifications can exempt either the entire service sector or a portion thereof from the obligations, thereby potentially eliminating the usefulness of the national treatunent and market access provisions. Id. at 374.

152. See id.; see also Platt, supra note 142, at 196.

153. Zebinsky, supra note 33, at 393-94.

154. Id. at 388-90. Zebinsky also points to several areas where the Chicago Convention is silent on issues, id. at 389, but the GATS has specific provisions dealing with these same issues. Id. He lumps those omissions together with the conflicts, id. at 388-90, as if to imply that they are both equally problematic. Such an inference, however, should not be drawn. The silence of the Chicago Convention is better interpreted as just that-silence. It neither expresses approval nor disapproval for any specific measure the GATS addresses that the Convention omitted.

155. Id. at 388. 
cause a nation would be required to allow other countries' airlines into its sovereign airspace if it allows even a single foreign nation's aircraft to enter. More importantly, for purposes of judging the efficacy of the GATS as a vehicle for multilateralisin in air transport, the GATS actually may discourage nations froin liberalizing their trade because "a inultilateral agreeinent predicated on mostfavored-nation would engender excessive caution on the part of governments otherwise inclined to be generous in extending inarket access opportunities to like-minded trading partners."156 Furthermore, States with restrictive domestic regulatory systems would have no incentive to hiberalize their domestic narkets because they could enter the deregulated inarkets of some nations and only have to offer in return what they provide to their domestic carriers-burdensome regulations. ${ }^{157}$ Finally, the industry has expressed concerns that the national treatinent and MFN clauses would result in a mass influx of airlines into nations with more hiberal route access while the skies over more restrictive nations would remain closed. ${ }^{158}$

As it stands now, the GATS is not the best vehicle for achieving multilateralisin successfully. Even if States evaluated GATS using the yardstick of optimal public service with overall sectoral balance ${ }^{159}$ the GATS is unlikely to satisfy the expectations of the affected parties. Although the travelling public probably would have expanded international service from more gateways to more destinations, this benefit would be swallowed up by the inequalities in the overall balance of rights exchanged. Nations with geographically sinall doinestic inarkets would gain disproportionate access to routes in comparison to larger nations. In fact, for some nations, no excliange would take place at all. Rather, countries such as the United States, which have more open traffic rights agreements, would be forced to admit airlines from all of the GATS contracting states. The contracting States, lowever, would not be required

156. WATC92, supra note 52, § 1.15 , at 3 (statement of Jeffrey N. Shane, Assistant Secretary for Policy and International Affairs, U.S. Department of Transportation); see also Zebinsky, supra note 33, at 393.

157. GATT-Airline Hearing, supra note 55, at 57 (statement of Roger D. Hall, Air Line Pilots Association); KASPER, supra note 15, at 104.

158. See GATT-Airline Hearing, supra note 55, at 53 (statement of James E. Landry, Air Transport Association of America).

159. See supra text accompanying notes 120-22, 131-34 for a brief explanation of these concepts and their possible uses. 
to offer anything in return: Thus, GATS in its present form does not provide an effective inultilateral solution to the problems currently faced by international aviation.

Although some of the criticism by scholars of the GATS is deserved, several of the difficulties can be remedied. No actual conflict with the Chicago Convention exists because the Convention permits the formation of multilateral agreenents without violating its terms. ${ }^{160}$ Most bilateral agreements today allow for the creation of a superseding multilateral pact, and state that bilateral obligations will yield to the extent that they conflict with a multilateral agreement. ${ }^{161}$ Furthermore, the GATS' Annex on Air Transport states that "any specific commitment or obligation assumed under this Agreement shall not reduce or affect a Member's obligations under bilateral or multilateral agreements that are in effect."162 Therefore, according to the terms of the Annex, the Chicago Convention and its provisions already in effect would take precedence over the GATS measures.

Modification of the GATS provisions, by using the sectoral Annex to apply the changes specifically to air transport, presents another possibility for turning GATS into a better trade liberalization tool. One technique would alter the nature of the MFN obligation to make it a "conditional MFN under which countries that mutually agree to accept higher levels of obligation should not be required to extend the same treatment to countries which were unwilling to do so."163 Although this option also has some drawbacks, especially for weaker aviation powers with small markets, ${ }^{164}$ it does help to resolve part of the overall imbalance of the current GATS system.

Another commentator has suggested that a different interpretation of the GATS language could avoid the pitfall of an unequal exchange. The MFN idea of "no less favourable treatinent" does not oblige nations to provide equal grants of traffic rights to all nations. ${ }^{165}$ In the alternative, nations could be grouped according to nondiscriminatory market criteria such as their competitive strength, and, on that basis, contracting parties would accord no

160. See supra note 95 and accompanying text.

161. Zebinsky, supra note 33, at 390.

162. Final Act, supra note 44, Annex on Air Transport Services, at 1188.

163. Platt, supra note 142, at 195 n.117; Zebinsky, supra note 33 , at 385 .

164. Platt, supra note 142 , at 195 n.117.

165. Wassenbergh, supra note 6 , at 178 . 
less favorable treatment to similar types of nations as opposed to all nations. ${ }^{166}$ Finally, in the event that a nation is overwhelmed with foreign imports of airline service causing serious injury to domestic providers, the GATS could have a safeguard escape clause similar to the GATT provision allowing for the affected country to take necessary steps to protect that industry from serious harm due to imports. ${ }^{167}$

Though the GATS endeavor involves numerous States, a handful of States concluded a more far-reaching multilateral aviation accord several years earher. The Andean Pact nations (Bohvia, Colombia, Ecuador, Peru, and Venezuela) agreed to a traffic rights exchange granting each other all five freedoins of the air but with a gradual transition into the fifth freedom, which would permit the airlimes to carry passengers to inultiple destinations in any of the countries on one route. ${ }^{168}$ This decision applies to all types of commercial flights, including nonscheduled and cargo flights. ${ }^{169}$ In addition, nations are permitted to designate inultiple national airlines to serve any of the destinations within the region. ${ }^{170}$ The Agreement also appoints the Andean Committee of Aeronautical Agencies to oversee this trade liberalization process. ${ }^{171}$ With respect to the implementation of the accord, the Committee is responsible for sucl matters as recommending solutions to problems that arise, suggesting objectives and policies to advance air transport, and most importantly, developing "jomt positions for negotiations with third parties that allow for obtaining the maximum benefits for the Subregion." 172 The significance of this responsibility lies in its potential to spur new links for trade in air transport among other regions, and it signals the Andean nations' willingness to consider other agreements. Therefore, the Andean Pact nations may intend to act as a negotiating bloc and use their stronger position as a group for leverage in any future bilateral or multilateral agreements. ${ }^{173}$

166. Id. Wassenbergh emphasizes that criteria such as market size or national population are discriminatory factors upon which the allocation of traffic rights should not be based. Id.

167. ŻYLICZ, supra note 2, at 174 .

168. Andean Pact, supra note 48, arts. 4, 5, 11.

169. Id. art. 2 .

170. Id. art. 9.

171. Id. art. 13.

172. Id. art 15 .

173. Bob Booth, Open Skies Over the Andes, AIRLINE BuS., Sept. 1991, at 81. In fact, 
The Andean Pact has several implications for international air services within the region. First, the Pact has expanded routes and improved the frequency of service for passengers. ${ }^{174}$ Since 1989 air travel has increased by $400 \%$ among the Andean nations, ${ }^{175}$ and the provisions of the Pact have presided over this tremendous growth for most of that period. In addition, Peru's Faucett Airlines foresees the imitiation of new service to "secondary cities" that currently lack any connection to an air transport network. ${ }^{176}$ Furthermore, the introduction of new carriers into Andean markets that traditionally have been restrictive should heighten competition and lower costs; in turn, both the consumer and the nation should benefit from this change through increased tourisin if more passengers opt for air transport due to its lower cost and greater convenience. ${ }^{177}$

Enthusiasn for the Pact, lowever, is not shared by all the interested parties. The president of Colombia's Avianca Airlines thinks the Agreenent "was a shock treatment executed with very little prior study and without taking into account the reahty of air transportation within the subregion, which has been negatively affected by a number of factors which are out of the control of the airlines themselves." 178 The Andean carriers possibly could conbat these factors, namely privatization of national airlines, leightened global conipetition, and greater trade liberalization, through a pooling arrangement, which would now be permitted under the Pact. The airlines could combine their resources, such as aircraft, ground handling, and coniputer reservation services to create their own economies of scope on par with the inega-carriers of Europe and the United States. ${ }^{179}$

at the 1994 World-Wide Air Transport Conference, the Andean Pact nations presented a united front and participated in discussions as a group. ICAO Conference 94, supra note 90, Agenda Item 3.1, at 51 .

174. Booth, supra note 173 , at 80 . The Pact should help to reduce costs to consumers as well. By allowing the region's airlines to serve more destinations more often while using the same aircraft, these airlines can achieve greater economies of scope that should result in lower fares. See supra notes 103-06 and accompanying text.

175. Andean Pact Airlines Form New Association to Integrate Air Travel, WORLD AIRLINE NEwS, Sept. 20, 1993, at 1.

176. Booth, supra note 173 , at 81 .

177. Id.

178. Id. at 81-82.

179. Id. at 84 . 
When evaluated by the measures of optimal public service benefit and overall sectoral balance, the Andean Pact does well. On the public service front, the Pact has demonstrated great potential for expanding access to air transport for millions of citizens in the region who previously were without service and for raising the frequency of service for those already with access. With respect to sectoral balance, the balance among the markets and airlines in the region appears to be equitable as well. Thus, the Andean Pact possesses the ability to perform as a good medium for trade liberalization within the region.

The Pact also may be used as a model for a global multilateral agreement. The Andean Pact nations and their airlines do enjoy demographic, economic, and cultural similarities; nonetheless, their experience with a multilateral aviation accord can be instructive for other nations pursuing the same path, either on a regional or worldwide basis. Although these nations' airlines may be significantly sinaller than those of the Uinted States, ${ }^{180}$ the nations themselves do share similarities in terms of size and trade with other nations in the western hemisphere. As a group, the Andean Pact countries would rank third in terms of population and foreign trade and fiftl in terms of gross domestic product. ${ }^{181}$ Hence, the aviation experience of the Andean Pact would not be isolated and distinct from that of the rest of the world. Of course, the immediate and unconditional grant of all five freedoms on a global basis would be difficult to transfer directly to a worldwide multilateral agreement. Certain provisions, however, such as inultiple airline designation on routes, ${ }^{182}$ the commitment to modify existing agreements to fit the "communitarian interest" and assure "sound competition," and the pledge to seek "quality and efficiency" in international air transport services, ${ }^{183}$ could be written into and applied in a future multilateral treaty.

180. The Andean Pact nations have nine national flag carriers which carry approximately 14 million passengers annually with gross revenues of about $\$ 1.5$ billion. $I d$. at 82.

181. Id.

182. Andean Pact, supra note 48, art. 9, at 1307. Multiple airline designation on routes means that more than one carrier in each nation may serve a particular route.

183. Id. art. 7 , at 1306. 


\section{B. Alternative Multilateral Approaches}

Several other viable alternatives exist for reaching a multilateral accord. Like the Andean Pact, the idea of a regional or limited multilateral agreement has received support from several scholarly circles. ${ }^{184}$ The core of this concept rests in "a small group of States with liberal policies ... [negotiating] a reciprocal exchange of commercial opportunities leading to an open air transport market, which other States could join later, and by whose liberal conditions the later additions must abide."185

A number of elements would be essential for a successful conclusion of a limited or regional multilateral treaty. First, the initial group of countries should be those with similar or reconcilable air policies and goals, hiberal or market-based economies, and unsubsidized airlines. ${ }^{186}$ Next, the cherished principles of the Chicago Convention, sovereignty of airspace and equality of opportumity in international air services, also should be preserved. ${ }^{187} \mathrm{Al}-$ though sovereignty and equality of opportunity would still be included, they could not (and mdeed should not) liold the paramount position of importance that they now hold under the current bilateral system. More open competition could drive a nation's carriers out of particular international route markets, and the current understanding of these principles would be inconsistent with that result. Rather, these principles, especially equality of opportunity, should be interpreted with an einphasis on "opportumity." Finally, appropriate safeguards and escape clauses should be built into any agreement to prevent or correct any unfair coinpetitive opportunities or practices by airlines and to provide for other legitimate state concerns. ${ }^{188}$

184. See KASPER, supra note 15, at 117-18; ŻYICZ, supra note 2, at 183-85; Lipman, supra note 54, at 156-57; Stockfish, supra note 88, at 643-46; see also Assad Kotaite, Multilateralism: A View from ICAO, in AIR TRANSPORT LAW AND POLICY IN THE 1990s: CONTROLlING THE BOOM 89, 98-99 (Pablo Mendes de Leon ed., 1991); Platt, supra note 142 , at $197-98$.

185. Lipman, supra note 54 , at 156.

186. Id; see also KASPER, supra note 15 , at 117 (noting that this approach would simplify negotiations); ŻYLICZ, supra note 2, at 132 (stressing the feasibility of reconciling conflicting policies within a group of countries that share a common interest).

187. See Kotaite, supra note 184 , at 97 . In fact, the Chicago Convention provides no guarantees-nor should any multilateral agreement-that a nation's airlines inust be able to operate international routes; instead, it seeks to ensure a "fair opportunity" for operation of those routes. See Chicago Convention, supra note 4, art. 44, at 326.

188. ŻyLICZ, supra note 2, at 190. These safeguards should not be used as guises for 
A number of benefits for international aviation and its legal framework could be realized through this limited multilateral approach. Initially, an agreement among like-minded nations would eliminate the least-common-denominator danger inherent in a large multilateral treaty where the liberalizing measures are reduced to the level acceptable by the most protectionist state. ${ }^{189}$ Accordingly, a sinall group of nations would be better able to pursue the goal of trade hiberalization in air services without the pressures of more restrictive States to lower their ambitions. ${ }^{190}$ Participating nations and their airlines also would benefit through greater efficiency and lower expenses as a result of the reduction and harmonization of regulations governing the operation of the industry. ${ }^{191}$ Moreover, a limited multilateral accord eventually could serve as the springboard for a more inclusive treaty by allowing other nations to jom the accord when they are prepared to accept its nore hiberal terns or by permitting various regional groups to negotiate with one another on a more equal footing for access to the other's joint airspace. ${ }^{192}$

With every legal arrangeinent, liowever, some risks are present. In the case of regional or limited multilateral accords, "[c]onsolidation of the position of one bloc may provoke creation or stiffening of other blocs, and strengthen defensive and protectionist tendencies im other parts of the world."193 If this type of arrangement is also to be utilized as a cornerstone for wider nultilateralisin, it must avoid the danger of creating significant imbalances among airlines or national markets as other coumtries and routes are added to the agreement. ${ }^{194}$ These pitfalls, however, are only potential probleins, and although they should be momtored, they should not inhibit serious consideration of a limited or regional multilateral agreement as a viable alternative for liberalization of international air services.

A closely related alternative would create what might be terned a step-by-step multilateral pact. This type of plan would

protectionism by a country whose airlines are not competitive or economically healthy in such a hiberal trade environment. See supra Part III.

189. KASPER, supra note 15 , at 117 .

190. Id.

191. Stockfish, supra note 88 , at $645-46$.

192. Id.

193. ŻYLICZ, supra note 2 , at 132.

194. Lipman, supra note 54, at 156. 
cover all nations simultaneously but permit them to accept varying levels of hiberalization of commercial air rights at their own pace. ${ }^{195}$ "Progressive simplification" would be the method by which States would advance toward more liberal traffic rights and deregulation of domestic markets. ${ }^{196}$

A third option would act more as a preventive measure to protect those countries that had entered into more open trade agreements for international air services. "Tariff bindings" are the mechanism to do this, and they are a concept borrowed from the GATT. ${ }^{197}$ Bindings function as

doubly contingent promises. ... [B]indings are made in exchange for the promises of others (that is, concessions). Unlike a contract at common law, however, a binding may be withdrawn without putting a party in breach of the agreement. Rather, the other parties have the right to withdraw proinises (concessions) inade in exchange for the withdrawn binding. Damages are thus linited to the withdrawal of concessions inade in rehance on the retracted commitment. ${ }^{198}$

The use of tariff bindings would give the parties legal redress if one party fails to meet its promised liberalizing commitments, thereby providing a form of insurance to those parties that want to liberalize but do not want to be trapped in a potentially unfair agreement. ${ }^{199}$

Should more comprehensive multilateral efforts fail, still another alternative would provide guidelines rather than a complete method for facilitating more open trade in imternational air services. Nations would engage in "enliglitened protection," nieaning that their aviation policies would promote growth of markets and routes by not taking actions like freezing capacity levels when the market can sustain more traffic. ${ }^{200}$ Whatever option the global community cliooses as the vehicle for liberalization, its primcipal objective should be the creation of a liberal trade regime to which nations would aspire, rather than the disinantling of trade barriers that nations would begrudgingly accept. ${ }^{201}$ Otherwise, countries

195. See ŻYLICZ, supra note 2, at 193; see also Platt, supra note 142, at 197.

196. Kotaite, supra note 184, at 98; see also ŻYLICZ, supra note 2, at 186-87.

197. KASPER, supra note 15 , at $109-10$.

198. Id.

199. Id. at 110.

200. Wassenbergh, supra note 6 , at 177 .

201. See KASPER, supra note 15, at 99-100. 
could hold any agreement hostage by using their trade barriers as "bargaining chips" to slow down or reduce the level of liberalization. ${ }^{202}$

\section{CONCLUSION}

The legal structure supporting and influencing international air transport services las arrived at a critical juncture in its evolution. It can continue to perform in its present bilateral role, barely serving the current needs and level of international travel but lacking the means to complement the growth potential of aviation in the coming decades. Instead, that legal framework can be transformed into a dynamic and capable inultilateral tool for opening and expanding markets to meet the deinands and requirements of the travelling public while promoting the objectives of States. The first option, the status quo, is the path of least resistance and will be the default choice if no action is taken by the interested States. Unlike the status quo, the alternative is a inultilateral approach that will require significant amounts of work on the part of all the parties and is frauglit witl potential risks for the participants. The potential results, lowever, hold greater promise.

Nations and their airlines liave the opportunity to resliape the direction and revitalize the promise of international air transport. The sliortcomings of the present bilateral system liave left the industry and its passengers with a restricted future, and although coinpreliensive nultilateralism may be a remote goal, it is a goal wortl the effort. ${ }^{203}$ The first step toward this goal rests in the search for cominon ground, mcentives, and motivations, To begin that searcl, "States pursuing liberal nultilateralism [nust] agree to ditch much of the outdated thinking which is still used to justify the protectionist rationale of many bilaterals-protection of perceived national, political and economic interests, which often comes to mean simply protecting the national airlines."204 That

202. Id.

203. ZYYICZ, supra note 2 , at 54 .

204. Lipman, supra note 54, at 157. 
"outdated thinking" should be replaced by an approach that focuses on the maximization of airline service to the public while maintaining an overall balance of burdens and benefits. Only then will the stage be set for the "step forward" envisioned in 1948: the regulation of international air transport services. 